\title{
Study of Natural Cytotoxicity Receptors in Patients with HIV/AIDS and Cancer: A Cross-Sectional Study
}

\author{
Orlando Nascimento Terra Junior, Gabriel de Carvalho Maldonado, \\ Guilherme Rohem Alfradique, Vinicius da Cunha Lisboa, Adriano Arnóbio, \\ Dirce Bonfim de Lima, Hilda Rachel Diamond, and Maria Helena Faria Ornellas de Souza
}

School of Medical Sciences, Rio de Janeiro State University, Professor Manoel de Abreu Avenue 444, 20550-170 Rio de Janeiro, RJ, Brazil

Correspondence should be addressed to Orlando Nascimento Terra Junior; orlando_ntj@hotmail.com

Received 18 January 2016; Revised 11 April 2016; Accepted 18 April 2016

Academic Editor: Antonella d’Arminio Monforte

Copyright (C) 2016 Orlando Nascimento Terra Junior et al. This is an open access article distributed under the Creative Commons Attribution License, which permits unrestricted use, distribution, and reproduction in any medium, provided the original work is properly cited.

\begin{abstract}
The NCR receptors play a fundamental role in the cytotoxicity mediated by NK cells against tumor cells. In the current study, we investigated possible HIV/AIDS-related changes in the expression of the NCR receptors comparing healthy donors, HIV/AIDS patients, and HIV/AIDS patients with cancer (HIV/AIDSWC). The NCRs were quantified in NK cells ( $\mathrm{NK}^{\mathrm{dim}}$ and $\mathrm{NK}^{\text {bright }}$ ) and T lymphocytes from peripheral blood samples by flow cytometry. We found a significant decrease in the frequency of NK cells expressing NKp46 in HIV/AIDS group $(p=0.0012)$. There was a decrease in the frequency of NK cells expressing NKp46 in the HIV/AIDSWC group; however, this was not statistically significant. We found a significant decrease in the frequency of NK cells expressing NKp30 in the HIV/AIDS group $(p=0.0144)$. There was a decrease in the frequency of NK cells expressing NKp30 and in the HIV/AIDSWC group, but this was not statistically significant. There were no changes in the distribution of NK cells and their subtypes in both groups.
\end{abstract}

\section{Introduction}

HIV-1 infection is characterized by a decline of $\mathrm{CD} 4^{+}$ lymphocyte levels and systemic immune hyperactivation [1] These factors, when associated, lead to exhaustion of immune resources and an increased risk of cancer [2], such as Kaposi's sarcoma (KS) caused by human herpes virus 8 (HHV-8), the non-Hodgkin lymphomas (NHL), some of which are caused by Epstein-Barr virus, and cervical cancer caused by oncogenic subtypes of human papillomavirus (HPV) [3]. These tumors are known as AIDS-defining cancers by the Disease Control and Prevention Center (CDC) [4]. People infected with HIV-1 also have an increased risk of a number of non-AIDS-defining cancers [2, 4], including some associated with coinfections or cigarette smoke $[5,6]$.

NK cells are a subset of lymphocytes that are capable of eliminating malignantly transformed or infected cells. This population of cells is primarily in peripheral blood and bone marrow, although it can be found in secondary lymphoid organs [7]. There are two distinct subtypes of NK cells based on the density of the surface expression on CD56. Over $90 \%$ of NK cells belong to the CD56 ${ }^{\mathrm{dim}}$ subtype, which has as its main function cytotoxicity and is rich in granzyme and perforin [7]. The second subtype, CD56 $6^{\text {bright }}$, is rare in the blood $( \pm 10 \%)$ and is responsible for the production of cytokines [7].

The precise mechanisms through which NK cells recognize and eliminate malignant or virus infected cells are complex and still not fully understood [8]. Unlike other lymphocytes, NK cells do not have receptors for specific antigens. Their cytolytic activity and cytokine production are regulated through activation or inhibition of receptors on their surface [7]. These receptors compose distinct families of proteins: lectin-like domains (CD94/NKG2A, HLA-E ligand with inhibitory function and NKG2D, and MIC-A ligand with activating function), immunoglobulin-like domains (KIR), and natural cytotoxicity receptors (NCR), where NCRs represent a family of characteristic NK cell markers [8]. 
There are three types of NCR receptors: NKp46, Nkp44, and NKp30. These receptors play a fundamental role in the cytotoxicity mediated by NK cells against tumor cells, whereas there is a close correlation between the expression density of the NCR on NK cells and their ability to kill tumor targets [9-11]. However, the ligands of these receptors in tumor cells have not yet been identified [8].

Previous studies have observed changes in the NCRs in HIV-1 infection [11-13]. These changes play a crucial role in some neoplasms mainly in cases of immunodepression where these receptors tend to be underexpressed [12, 14].

From a cancer perspective, prior studies observed changes in expression of NCRs in patients with malignancies, which in part is explained in the tumor microenvironment that is capable of overactive certain inflammatory responses by secreting proinflammatory cytokines that allow increased expression of these receptors $[15,16]$. However, studies that observe functional changes of the NK cells in patients with both conditions are scarce.

The role of cancer in changing the profile of these cells in HIV/AIDS or if the prevalence of cancer in these groups is directly related to changes in these receptors given their crucial role in the monitoring of malignant cells is still uncertain.

The aim of this study was to evaluate the expression of NCR receptors in the NK cells (and their subtypes) and to compare HIV/AIDS patients and HIV/AIDS patients with cancer (HIV/AIDSWC). This study offers new unexpected viewpoints of the role of $\mathrm{NK}$ receptors and their possible exploitation in a growing range of diseases, like cancer.

\section{Methods}

2.1. Study Design. This was an observational study that used a cross-sectional approach conducted from 2014 to 2015 at the Department of Infectious and Parasitic Diseases of the Pedro Ernesto University Hospital, Rio de Janeiro State University, RJ, Brazil.

2.2. Study Subjects. The patients (groups HIV/AIDS and HIV/AIDSWC) were recruited at the Department of Infectious and Parasitic Diseases, Pedro Ernesto University Hospital, Rio de Janeiro State University, RJ, Brazil. HIV-1 diagnosis was made through a standard screening enzymelinked immunosorbent assay (ELISA; Elecsys ${ }^{\circledR}$ HIV combi PT) and confirmed by Immunoblotting (Imunoblot Dual Path Platform (DPP $\left.\left.{ }^{\circledR}\right) \mathrm{HIV}-1 / 2\right)$.

The inclusion criteria for the patient groups included the following: confirmed diagnosis of HIV/AIDS formally registered in medical records; age of 18 years or more; and having started antiretroviral treatment (HAART); and for the HIV/AIDSWC group they included confirmed diagnosis of cancer registered formally in medical records and being treated against cancer.

The exclusion criteria included the following: opportunist infections within 6 months, diabetes, and autoimmune diseases. To ensure that such conditions were not included in the groups, an analysis of the medical records of all patients captured for study was conducted. There were no exclusion criteria from the point of view of the medicines used for the treatment of HIV/AIDS and cancer.

The samples from the groups HIV/AIDS and HIV/ AIDSWC were obtained from peripheral blood at the Nucleic Acids Laboratory of the Pedro Ernesto University Hospital, RJ, Brazil.

Healthy donors were recruited at the Department of Pathology and Laboratory, School of Medical Sciences, Rio de Janeiro State University, RJ, Brazil. For the recruitment of healthy donors, an interview was conducted, and when there was no declaration of infections within 6 months, cancer, diabetes, immunologic illness, or current use of immunomodulatory medications, blood samples were collected. A second screening was performed based on laboratory examinations and clinical records, and individuals presenting anomalies and other conditions that could affect the immune system were excluded.

All samples ( $5 \mathrm{~mL}$ of peripheral blood) were collected into a tube containing ethylenediamine tetraacetic acid (EDTA).

2.3. Ethics. This study was approved by the Ethics Committee of the Hospital Universitário Pedro Ernesto/UERJ (CAAE 14189113.2.0000.5259). All samples were collected with written informed consent.

2.4. Reagents. Anti-CD3-FITC clone UCHT1, anti-CD56PC5 clone N901, anti-CD335-PE (NKp46) clone BAB281, anti-CD336-PE (NKp44) clone Z231, and anti-CD337-PE (NKp30) clone Z25 were obtained from Beckman Coulter (Fullerton, CA). The BD Multitest contained anti-CD3-FITC (clone SK7), anti-CD8-PE (clone SK1), anti-CD45-PercP (clone 2D1), and anti-CD4-APC (SK3) were obtained from BD Biosciences (San Jose, CA).

Anti-CD335-PE, anti-CD336, and anti-CD337 were used for the analysis of NCR family member expression. The BD Multitest was used for the quantification of the Tlymphocytes $\mathrm{CD}^{+}$and $\mathrm{CD}^{+}$. The anti-CD3-FITC and anti-CD56-PC5 were used for identification of the lymphocytes groups.

2.5. Flow Cytometry. The samples were stained with specific monoclonal antibodies $(5 \mu \mathrm{L}$ of each monoclonal antibody was added to $100 \mu \mathrm{L}$, approximately $1 \times 10^{6}$ leukocytes of peripheral blood with EDTA) and incubated at room temperature for $15 \mathrm{~min}$ in the dark. The red blood cells were lysed with a FACS Lyse reagent (BD Biosciences, San Jose, CA) and centrifuged at $2000 \mathrm{rpm}$ for $5 \mathrm{~min}$. The supernatants were discarded, and the cells were washed twice with phosphatebuffered saline (PBS) and resuspended in $200 \mu \mathrm{L}$ of PBS. At least 200,000 events were acquired using a FACScanto II flow cytometer (BD Biosciences, San Jose, CA), and data were analyzed using the FACS Diva (BD Biosciences, San Jose, CA).

2.6. Gate Draw. Before gate draw, the dead cells and conjugates (doublets) were excluded from the analysis. For the gate draw in the lymphocytes population, side scatter (SSC) and forward scatter (FSC) were used. The antibodies anti-CD3 
TABLE 1: Baseline Characteristics from subjects in different groups.

\begin{tabular}{lccccccc}
\hline & $\begin{array}{c}\text { Number of } \\
\text { females/males }\end{array}$ & Age in years ${ }^{\mathrm{a}}$ & $\begin{array}{c}\text { Days since } \\
\text { HIV/AIDS } \\
\text { diagnosis }^{\mathrm{a}}\end{array}$ & $\begin{array}{c}\text { Viral load HIV } \\
\text { RNA/mL } \\
\text { (range) }^{\mathrm{b}}\end{array}$ & $\begin{array}{c}\text { CD4/CD8 } \\
\text { ratio }^{\mathrm{a}}\end{array}$ & $\begin{array}{c}\text { HAART } \\
\text { treated }^{2}\end{array}$ & $\begin{array}{c}\text { Days since } \\
\text { cancer }^{\text {diagnosis }}\end{array}$ \\
\hline Healthy donors & $1 / 24$ & $43(20-65)$ & NA & NA & NA & NA \\
HIV/AIDS & $5 / 20$ & $45(19-69)$ & $4437(419-9267)$ & $(<40-512.000)$ & $\begin{array}{c}0.71 \\
(0.11-1.57)\end{array}$ & Yes & NA \\
HIV/AIDSWC & $4 / 17$ & $45(30-69)$ & $2628(88-8679)$ & $(<40-113.000)$ & $\begin{array}{c}0.40 \\
(0.04-1.35)\end{array}$ & Yes & $(40-7488)$ \\
\hline
\end{tabular}

${ }^{\mathrm{a}}$ The median (range) for each group is shown. ${ }^{\mathrm{b}}$ Only the range for each group is shown. The HIV/AIDSWC group had eight patients with viral load classified as "undetectable." The HIV/AIDS group had eighteen patients with viral load classified as "undetectable." These patients are not included in the table. NA: not applicable.

TABLE 2: Treatment regimen in HIV/AIDS group and HIV/AIDSWC group.

\begin{tabular}{lcc}
\hline Treatment regimen & $\begin{array}{c}\text { Number of patients } \\
\text { of the HIV/AIDS } \\
\text { group }\end{array}$ & $\begin{array}{c}\text { Number of patients } \\
\text { of the } \\
\text { HIV/AIDSWC } \\
\text { group }\end{array}$ \\
\hline NRTI + NNRTI + PI + & - & 1 \\
FI & 1 & 3 \\
NRTI + NNRTI + PI & 2 & - \\
NRTI + NNRTI + II & 14 & 11 \\
NRTI + NNRTI & 7 & 4 \\
NRTI + PI & 1 & 2 \\
NRTI & 1 & \\
\hline
\end{tabular}

NRTI: nucleoside/nucleotide reverse transcriptase inhibitors; NNRTI: nonnucleoside reverse transcriptase inhibitors; PI: protease inhibitor; FI: fusion inhibitors; II: integrase inhibitors.

and anti-CD56 (present in all tubes) were used to separate two cell populations: $\mathrm{T}$ cells $\left(\mathrm{CD}^{+} \mathrm{CD}^{-} 6^{-}\right)$and $\mathrm{NK}$ cells $\left(\mathrm{CD} 3^{-} \mathrm{CD} 56^{+}\right)$. The NK cells were subdivided based on CD56 expression in two subsets: NK CD56 ${ }^{\mathrm{dim}}$ and NK CD56 ${ }^{\text {bright }}$. Receptor expression of NCR was assessed separately for each of these populations. Gates strategies were designed based on Almeida-Oliveira et al. [7], as exemplified in Figure 1.

2.7. Statistical Analysis. Differences between groups were analyzed using the Kruskal-Wallis nonparametric test (with Student-Newman-Keuls posttest). Correlation analysis was performed using Spearman's test. Statistical analysis was performed using BioStat version 5.0 software.

\section{Results}

3.1. Baseline Characteristics of Subjects. We studied 71 subjects with ages ranging from 19 to 69 years. Our study population was divided into three groups: healthy donors $(n=25), \mathrm{HIV} / \mathrm{AIDS}$ patients $(n=25)$, and HIV/AIDS patients with cancer (HIV/AIDSWC) $(n=21)$. The patients' characteristics are shown in Table 1 . The types of HAART are shown in Table 2.

The types of cancer that composed the HIV/AIDSWC group were Kaposi's sarcoma (8) non-Hodgkin lymphoma
(8), anal carcinoma (1), fibrosarcoma (1), colon (1), mesenchymal cells (1), and Hodgkin lymphoma (1). At the time of collection, all patients were in treatment against the cancer.

3.2. Changes in Lymphocytes Populations. With flow cytometry, we defined the populations of interest based on CD3 and CD56 expression (Figure 1). The percentage of classical T cell population presented a slight increase in the HIV/AIDS and HIV/AIDSWC groups; however, no statistical difference was observed among the different groups nor in absolute number (Table 3). No differences were observed in the percentage of the total lymphocyte population among the different groups (Table 3).

The percentage of $\mathrm{CD}^{+}$and $\mathrm{CD}^{+}$subpopulations was affected by HIV/AIDS, as expected (Table 3 ). The groups HIV/AIDS and HIV/AIDSWC showed a decrease of the $\mathrm{CD}^{+}$percentage when compared with the healthy group $(p<0.0001)$. The same was found in absolute number $(p=0.0002)$. The HIV/AIDS and HIV/AIDSWC groups also showed a significant statistical difference in the CD ${ }^{+}$ percentage between themselves $(p<0.05)$. This difference was also observed in absolute number $(p<0.05)$.

The HIV/AIDS and HIV/AIDSWC groups showed an increase of the $\mathrm{CD}^{+}$percentage when compared with the healthy group $(p<0.0001)$. The same was found in absolute number $(p=0.0007)$.

No differences were observed in the percentage of the NK cell population among different groups (Table 3).

The HIV/AIDS and HIV/AIDSWC groups did not show statistical differences in the WBC count when compared to the healthy group (Table 3).

3.3. Changes in NK Cells Subsets. No differences were observed in the percentage of the CD56 ${ }^{\mathrm{dim}}$ cell population among different groups (Table 3 ). In addition, no differences were observed in the percentage of the CD56 ${ }^{\text {bright }}$ cell population among different groups (Table 3).

3.4. Changes in NCR Receptors. We investigated the expression of three receptors belonging to the NCR family: NKp44, $\mathrm{NKp} 46$, and NKp30. None of these receptors were expressed at considerable levels in T cells. In our study, the expression of NKp44 in the studied cells is not apparent in considerable levels. 


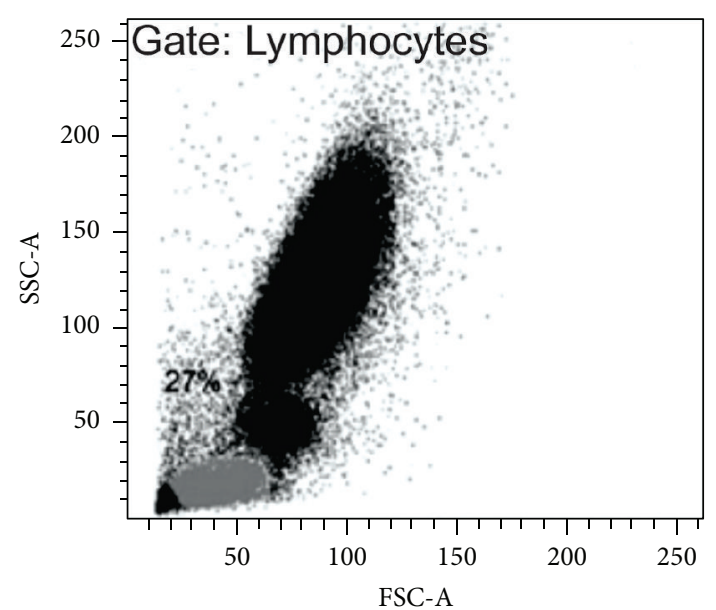

(a)

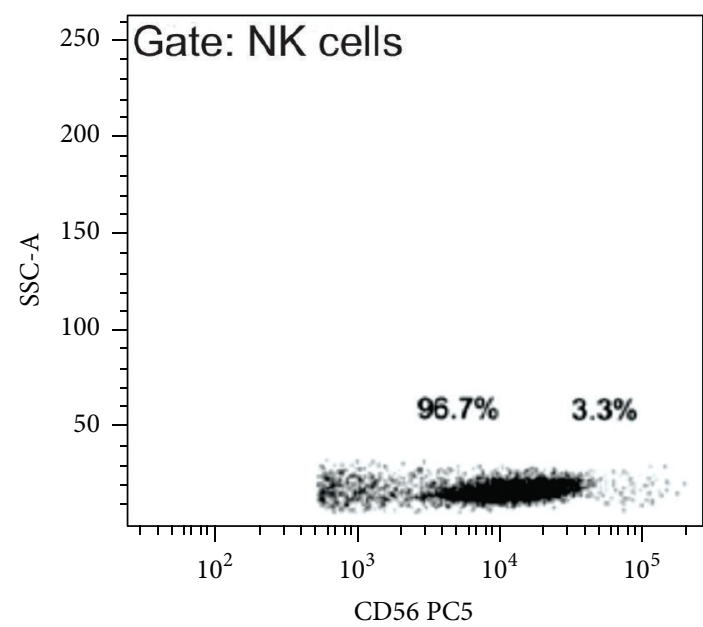

(c)

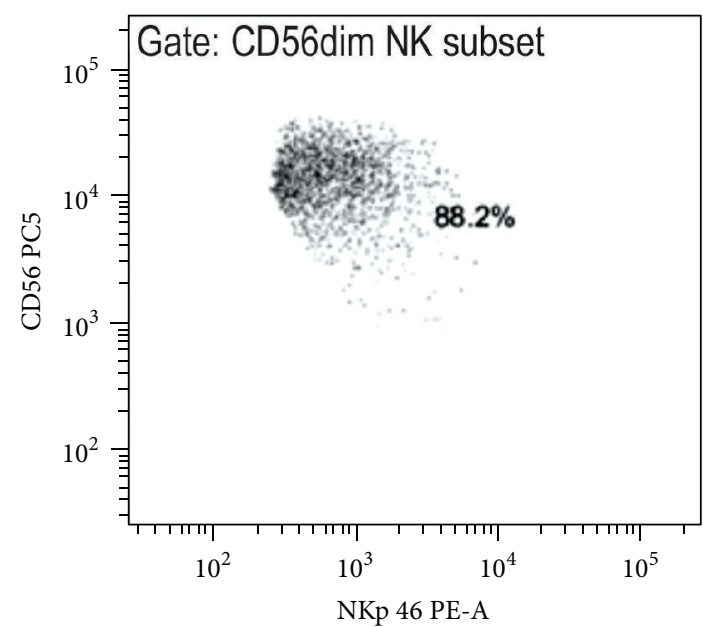

(e)

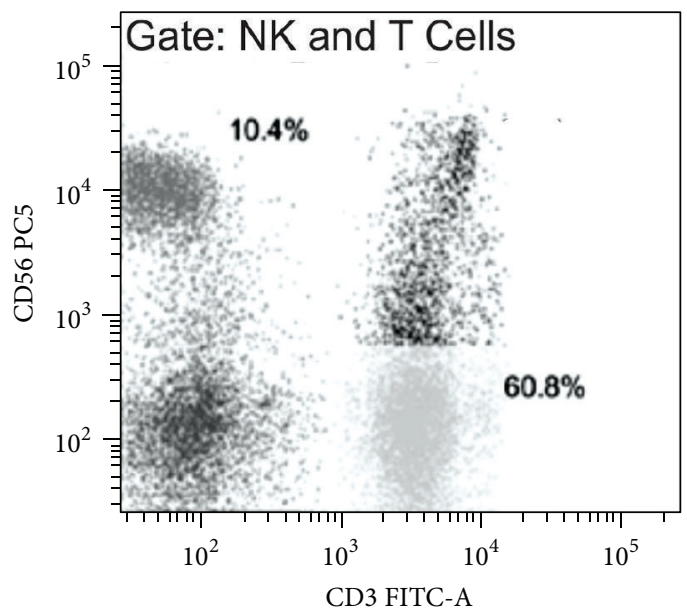

(b)

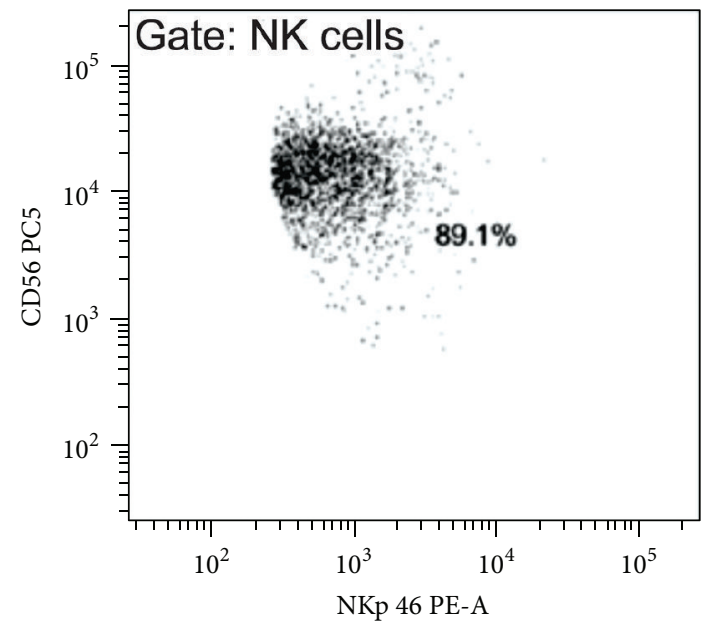

(d)

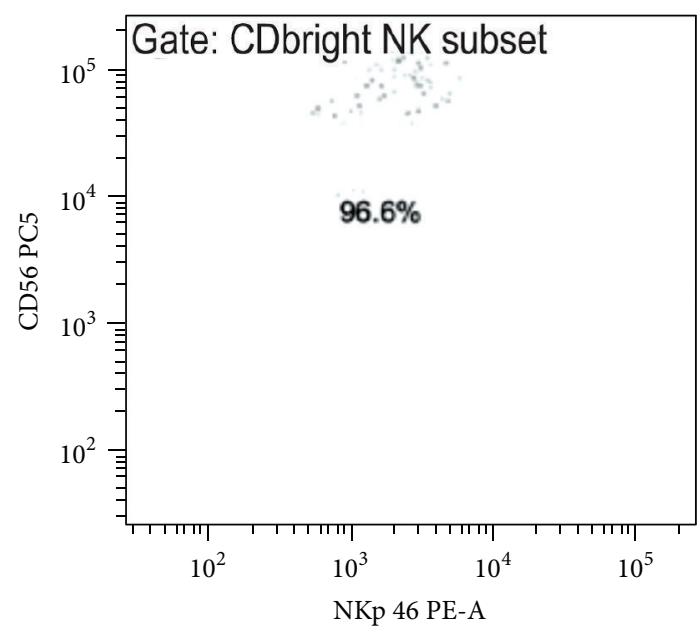

(f)

FIGURE 1: Gate strategy based on example of analysis of a healthy donor (male, age 31 years). Gate strategy: (a) lymphocyte population based on FCS and SSC. (b) Identification of cells populations based on CD3 and CD56 expression, T cells (CD3 $\left.{ }^{+} \mathrm{CD} 56^{-}\right)$, and NK cells $\left(\mathrm{CD} 3^{-} \mathrm{CD} 56^{+}\right)$. (c) Identification of NK cell subsets based on CD56 expression. $(\mathrm{a}-\mathrm{c})$ the frequency of each cell population is represented in percentage inside each graphic. (d-f) NKp46 expression in each of these cells populations, for example, in NK cells (d), NK CD56 ${ }^{\mathrm{dim}}$ subset (e), and NK CD56 ${ }^{\text {bright }}$ subset (f). (d-f) the frequency of NKp46 cells in each cell population is represented in percentage inside each graphic. 
TABLE 3: Frequency of T and NK (CD56 ${ }^{\mathrm{dim}}$ and CD56 $\left.{ }^{\text {bright }}\right)$ cells from subjects in different groups.

\begin{tabular}{|c|c|c|c|c|c|c|c|}
\hline & \multicolumn{3}{|c|}{ Median } & \multicolumn{3}{|c|}{ Mean \pm SD } & \multirow{2}{*}{$\begin{array}{c}p \text { value } \\
\text { (Kruskal-Wallis test) }\end{array}$} \\
\hline & Healthy & HIV/AIDS & HIV/AIDSWC & Healthy & HIV/AIDS & HIV/AIDSWC & \\
\hline \multicolumn{8}{|l|}{ Percentage (\%) } \\
\hline $\begin{array}{l}\text { Total } \\
\text { lymphocytes }\end{array}$ & 35.50 & 35.50 & 30.00 & $33.61 \pm 9.09$ & $35.44 \pm 10.44$ & $32.39 \pm 11.94$ & 0.3617 \\
\hline $\mathrm{T}$ cells & 55.20 & 59.40 & 57.70 & $54.48 \pm 11.54$ & $60.70 \pm 9.14$ & $57.52 \pm 11.28$ & 0.2204 \\
\hline CD4 T cells & 53.00 & $38.20^{\mathrm{a}}$ & $23.60^{\mathrm{ab}}$ & $54.44 \pm 11.12$ & $37.91 \pm 10.74$ & $26.28 \pm 14.99$ & $<0.0001$ \\
\hline CD8 T cells & 36.10 & $53.00^{\mathrm{a}}$ & $62.00^{\mathrm{a}}$ & $35.26 \pm 9.96$ & $53.12 \pm 10.32$ & $60.66 \pm 15.45$ & $<0.0001$ \\
\hline NK cells & 11.30 & 9.70 & 11.60 & $13.21 \pm 6.69$ & $11.15 \pm 7.08$ & $12.93 \pm 6.75$ & 0.4699 \\
\hline $\begin{array}{l}\text { CD56 }{ }^{\text {dim }} \mathrm{NK} \\
\text { subset }\end{array}$ & 96.50 & 95.70 & 94.80 & $95.72 \pm 2.94$ & $94.23 \pm 5.10$ & $93.70 \pm 5.14$ & 0.2499 \\
\hline $\begin{array}{l}\text { CD56 }{ }^{\text {bright }} \mathrm{NK} \\
\text { subset }\end{array}$ & 3.70 & 4.50 & 5.10 & $4.41 \pm 2.99$ & $5.26 \pm 4.14$ & $6.37 \pm 5.60$ & 0.3283 \\
\hline \multicolumn{8}{|l|}{$\begin{array}{l}\text { Absolute } \\
\text { numbers } \\
\left(\text { cells } / \mathrm{mm}^{3} \text { ) }\right.\end{array}$} \\
\hline WBC count & 7000 & 5500 & 6800 & $7148.00 \pm 2233.85$ & $5924.00 \pm 1860.17$ & $7261.90 \pm 2789.52$ & 0.0722 \\
\hline $\begin{array}{l}\text { Total } \\
\text { lymphocytes }\end{array}$ & 2280 & 1960 & 2110 & $2256.40 \pm 566.09$ & $2007.60 \pm 597.02$ & $2341.42 \pm 1152.39$ & 0.4601 \\
\hline $\mathrm{T}$ cells & 1159 & 1198 & 1314 & $1214.16 \pm 416.83$ & $1229.88 \pm 454.55$ & $1329.95 \pm 640.95$ & 0.8751 \\
\hline CD4 T cells & 655 & $453^{\mathrm{a}}$ & $280^{\mathrm{ab}}$ & $665.36 \pm 272.59$ & $472.56 \pm 228.92$ & $355.42 \pm 303.63$ & 0.0002 \\
\hline CD8 T cells & 369 & $603^{\mathrm{a}}$ & $753^{\mathrm{a}}$ & $430.08 \pm 209.90$ & $645.84 \pm 252.61$ & $812.38 \pm 437.61$ & 0.0007 \\
\hline NK cells & 274 & 194 & 248 & $292.20 \pm 173.04$ & $211.76 \pm 131.60$ & $310.28 \pm 235.15$ & 0.1501 \\
\hline $\begin{array}{l}\text { CD56 }{ }^{\text {dim }} \mathrm{NK} \\
\text { subset }\end{array}$ & 257 & 185 & 239 & $281.60 \pm 172.52$ & $203.32 \pm 131.54$ & $294.76 \pm 226.17$ & 0.1817 \\
\hline $\begin{array}{l}\text { CD56 } 6^{\text {bright }} \mathrm{NK} \\
\text { subset }\end{array}$ & 9 & 7 & 10 & $10.92 \pm 7.29$ & $7.72 \pm 4.92$ & $15.23 \pm 12.39$ & 0.1137 \\
\hline
\end{tabular}

Percentage values represent the frequency (in percentage and absolute numbers) in median of $\mathrm{T}$ cells, $\mathrm{CD} 4^{+} \mathrm{T}$ cells, $\mathrm{CD} 8^{+} \mathrm{T}$ cells, and NK cells among all peripheral blood lymphocytes and the frequency of CD56 ${ }^{\text {dim }}$ and CD56 bright $\mathrm{NK}$ cells among the NK cell population. Means and standard deviations (SD) are also shown. Significant $p$ values are highlighted in boldface type. a = statistical difference to the healthy group $(p<0.05)$; $\mathrm{b}=$ statistical difference to the HIV/AIDS group $(p<0.05)$. Statistical comparisons made by Kruskal-Wallis (with Student-Newman-Keuls posttest).

We found a significant decrease in the percentage of the frequency of NK cells expressing NKp46 in the HIV/AIDS group $(p=0.0012)$. This difference was also observed in absolute number $(p=0.0018)$. There was a decrease in percentage and absolute number of the frequency of NK cells expressing NKp46 in the HIV/AIDSWC group; however, it was not statistically significant (Table 4). We also found a significant decrease in the percentage of the frequency of CD56 ${ }^{\mathrm{dim}}$ cells expressing NKp46 in the HIV/AIDS group $(p=0.0008)$. This difference was also observed in absolute number $(p=0.0019)$. The HIV/AIDS and HIV/AIDSWC groups also showed a statistical difference in the frequency of NK cells and CD56 ${ }^{\mathrm{dim}}$ cells expressing NKp46 in percentage between themselves $(p<0.05)$. This difference was also observed in absolute number $(p<0.05)$.

A significant decrease in percentage of the frequency of NK cells expressing NKp30 in the HIV/AIDS group ( $p=$ $0.0144)$ was observed. This difference was also observed in absolute number $(p=0.0011)$. There was a decrease in percentage and absolute number of the frequency of NK cells expressing NKp30 in the HIV/AIDSWC group; however, these results were not statistically significant (Table 4). We also found a significant decrease in percentage of the frequency of CD56 ${ }^{\mathrm{dim}}$ cells expressing NKp30 in the HIV/AIDS group $(p=0.0286)$. This difference was also observed in absolute number $(p=0.0022)$. The HIV/AIDS and HIV/AIDSWC groups also showed a statistically significant decrease in the frequency of NK cells and CD56 $6^{\mathrm{dim}}$ cells expressing NKp30 in absolute number between themselves $(p<0.05)$. There was also a significant increase in expression of NKp30 in CD56 ${ }^{\text {bright }}$ cells in the HIV/AIDSWC group $(p=0.0275)$ in their absolute number. This difference was not observed in percentage (Table 4). The HIV/AIDS and HIV/AIDSWC groups also showed a significant difference in the frequency of $\mathrm{CD} 56^{\text {bright }}$ cells expressing NKp30 in absolute number between themselves $(p<0.05)$.

3.5. Correlation Analysis. Correlation analysis detected a positive correlation between the expression of NKp46 and NKp30 in total NK cells $(p<0.0001, \mathrm{rs}=0.9046)$ and their subtypes CD56 ${ }^{\mathrm{dim}}(p<0.0001$, rs $=0.9297)$ in the HIV/AIDS group.

A positive correlation was detected between the expression of NKp46 and NKp30 in total NK cells $(p<0.0001$, 
TABLE 4: Frequency of T and NK (CD56 ${ }^{\text {dim }}$ and CD56 $\left.{ }^{\text {bright }}\right)$ cells expressing NCRs receptors in different groups.

\begin{tabular}{|c|c|c|c|c|c|c|c|}
\hline & \multicolumn{3}{|c|}{ Median } & \multicolumn{3}{|c|}{ Mean \pm SD } & \multirow{2}{*}{$\begin{array}{c}p \text { value } \\
\text { (Kruskal-Wallis test) }\end{array}$} \\
\hline & Healthy & HIV/AIDS & HIV/AIDSWC & Healthy & HIV/AIDS & HIV/AIDSWC & \\
\hline \multicolumn{8}{|l|}{$\begin{array}{l}\text { Percentage (\%) of } \\
\text { NKp46 }\end{array}$} \\
\hline NK cells & 72.00 & $50.40^{\mathrm{a}}$ & $69.50^{\mathrm{b}}$ & $70.68 \pm 22.38$ & $48.03 \pm 19.10$ & $61.78 \pm 21.24$ & 0.0012 \\
\hline CD56 ${ }^{\mathrm{dim}} \mathrm{NK}$ subset & 72.50 & $43.00^{\mathrm{a}}$ & $59.60^{\mathrm{b}}$ & $70.13 \pm 22.80$ & $45.38 \pm 19.75$ & $59.69 \pm 22.13$ & 0.0008 \\
\hline CD56 $6^{\text {bright }} \mathrm{NK}$ subset & 93.90 & 92.50 & 95.10 & $93.28 \pm 5.19$ & $92.54 \pm 6.27$ & $93.26 \pm 6.51$ & 0.7706 \\
\hline \multicolumn{8}{|l|}{$\begin{array}{l}\text { Percentage }(\%) \text { of } \\
\text { NKp30 }\end{array}$} \\
\hline NK cells & 38.00 & $20.50^{\mathrm{a}}$ & 33.10 & $38.79 \pm 17.33$ & $24.90 \pm 13.99$ & $31.66 \pm 16.25$ & 0.0144 \\
\hline CD56 ${ }^{\mathrm{dim}} \mathrm{NK}$ subset & 41.00 & $21.30^{\mathrm{a}}$ & 32.20 & $39.27 \pm 15.96$ & $26.64 \pm 14.81$ & $32.21 \pm 17.22$ & 0.0286 \\
\hline CD56 ${ }^{\text {bright }} \mathrm{NK}$ subset & 11.80 & 10.30 & 14.40 & $11.44 \pm 6.63$ & $16.06 \pm 14.49$ & $15.60 \pm 7.82$ & 0.2068 \\
\hline \multicolumn{8}{|l|}{$\begin{array}{l}\text { Absolute numbers of } \\
\left.\text { NKp46 (cells } / \mathrm{mm}^{3}\right)\end{array}$} \\
\hline NK cells & 158 & $90^{\mathrm{a}}$ & $136^{\mathrm{b}}$ & $199.04 \pm 132.32$ & $99.68 \pm 74.37$ & $167.23 \pm 109.45$ & 0.0018 \\
\hline CD56 ${ }^{\mathrm{dim}} \mathrm{NK}$ subset & 145 & $79^{\mathrm{a}}$ & $127^{\mathrm{b}}$ & $190.16 \pm 131.71$ & $91.04 \pm 71.58$ & $154.14 \pm 106.78$ & 0.0019 \\
\hline CD56 ${ }^{\text {bright }} \mathrm{NK}$ subset & 8 & 7 & 10 & $10.24 \pm 6.78$ & $7.08 \pm 4.34$ & $14.09 \pm 11.07$ & 0.0754 \\
\hline \multicolumn{8}{|l|}{$\begin{array}{l}\text { Absolute numbers of } \\
\mathrm{NKp} 30 \text { (cells } / \mathrm{mm}^{3} \text { ) }\end{array}$} \\
\hline NK cells & 86 & $38^{\mathrm{a}}$ & $72^{\mathrm{b}}$ & $111.68 \pm 87.80$ & $49.32 \pm 41.16$ & $80.09 \pm 50.97$ & 0.0011 \\
\hline CD56 ${ }^{\text {dim }}$ NK subset & 83 & $42^{\mathrm{a}}$ & $69^{\mathrm{b}}$ & $108.44 \pm 83.95$ & $49.52 \pm 39.82$ & $75.76 \pm 48.23$ & 0.0022 \\
\hline CD56 ${ }^{\text {bright }} \mathrm{NK}$ subset & 1 & 1 & $2^{\mathrm{b}}$ & $1.32 \pm 1.31$ & $1.04 \pm 1.30$ & $2.42 \pm 2.20$ & 0.0275 \\
\hline
\end{tabular}

The values shown represent the percentage and absolute number in median within each cell population expressing a given receptor NCR. Means and standard deviations (SD) are also shown. Significant $p$ values are highlighted in bold. $\mathrm{a}=$ statistical difference to the healthy group $(p<0.05)$; $\mathrm{b}=$ statistical difference to the HIV/AIDS group $(p<0.05)$. Statistical comparisons were made by Kruskal-Wallis (with Student-Newman-Keuls posttest).

rs $=0.7580)$ and their subtypes $\operatorname{CD}^{\mathrm{dim}}(p=0.0003$, rs $=0.7156)$ and CD56 ${ }^{\text {bright }}(p<0.0001, \mathrm{rs}=0.8096)$ in the HIV/AIDSWC group.

A positive correlation was detected between the expression of NKp46 and NKp30 in total NK cells $(p<0.0001$, rs $=0.7272)$ and their subtypes $\operatorname{CD}^{2} 6^{\operatorname{dim}}(p<0.0001$, rs $=0.7838)$ and $\mathrm{CD}_{56} 6^{\text {bright }}(p<0.0001, \mathrm{rs}=0.7121)$ in the healthy donor group. A positive correlation was also detected between $\mathrm{CD}^{+} \mathrm{T}$ cells and the expression of NKp46 $(p=$ $0.0008, \mathrm{rs}=0.6241)$ and $\mathrm{NKp} 30(p=0.0009, \mathrm{rs}=0.6232)$ in CD56 ${ }^{\text {bright }}$ cells.

There was no correlation between the expression of NCR receptors (NKp46 and NKp30) and CD4 T cell count or CD4/CD8 ratio and infection duration in any of the patients groups studied (Table 5).

\section{Discussion}

4.1. Distribution of the Lymphocyte Subsets (NK and T Lymphocytes). The hallmark of HIV-1 infection is the selective depletion of the $\mathrm{CD}^{+} \mathrm{T}$ cell caused by HIV-1 tropism by this population of cells, due to the high affinity of the protein of the viral envelope through the CD4 receptor [17] and the depletion due to permanent immune activation by inflammatory cytokines in the chronic phase of infection [18]. This is reflected in the values presented in our study, where the HIV/AIDS and HIV/AIDSWC groups differed significantly in percentage and absolute values in comparison to the healthy group $(p<0.0001$ and $p=0.0002$, resp.). However, according to Horberg et al. [19], treatment with HAART increased the $\mathrm{CD} 4^{+}$count in patients with HIV/AIDS; this was not reflected in our study. In contrast, the proportion of $\mathrm{CD}^{+} \mathrm{T}$ cells increased after HIV/AIDS infection in both groups in percentage and absolute number in comparison to the healthy group ( $p<0.0001$ and $p=0.0007$, resp.). This increase is resonant with the findings of Naranbhai et al. [20] when studying the lymphocyte expansion in HIV-1 patients. It is important to mention that the use of certain HAART can directly affect the distribution of these cells, as demonstrated in the study of Hunt et al. [21], where the use of a drug called Maraviroc $^{\circledR}$ did not affect the cell recovery rate of $\mathrm{CD}^{+} \mathrm{T}$ cells but increased $\mathrm{CD}^{+} \mathrm{T}$ cells counts in peripheral blood.

The percentage and absolute values of the distribution of NK cells found by our study in the lymphocyte segment were compatible with the study by Alter et al. [22]. These authors observed no significant differences in all NK cells, including subsets (CD56 ${ }^{\mathrm{dim}}$ and CD56 ${ }^{\text {bright }}$ ). In this same study, the total percentage of NK cells observed in patients with acute infection proved to be significantly increased. However, in our study, the majority of individuals in the chronic stage of HIV/AIDS were studied. Together, these data suggest that the population of NK cells is usually expanded during acute infection, returning to similar levels of those observed in noninfected individuals $[20,22]$. 
TABLE 5: Correlation analysis between NCRs and CD4 T cells, CD4/CD8 ratio, and days since HIV/AIDS diagnosis.

\begin{tabular}{|c|c|c|c|c|}
\hline & NKp30 & CD4 T cells & $\mathrm{CD} 4 / \mathrm{CD} 8$ ratio & Days since HIV/AIDS diagnosis \\
\hline \multicolumn{5}{|c|}{ NK cells } \\
\hline \multicolumn{5}{|c|}{ Healthy donors } \\
\hline NKp46 & $0.7272(\mathrm{p}<0.0001)$ & $0.2585(p=0.2121)$ & $-0.1408(p=0.5019)$ & NA \\
\hline NKp30 & - & $0.1617(p=0.4400)$ & $-0.0004(p=0.9985)$ & NA \\
\hline \multicolumn{5}{|c|}{ HIV/AIDS group } \\
\hline NKp46 & $0.9046(\mathrm{p}<0.0001)$ & $0.2400(p=0.2477)$ & $0.1928(p=0.3559)$ & $0.0677(p=0.7478)$ \\
\hline NKp30 & - & $0.2821(p=0.1718)$ & $0.3249(p=0.1130)$ & $0.1428(p=0.4960)$ \\
\hline \multicolumn{5}{|c|}{ HIV/AIDSWC group } \\
\hline NKp46 & $0.7580(p<0.0001)$ & $0.3351(p=0.1375)$ & $0.0754(p=0.7454)$ & $0.0948(p=0.6827)$ \\
\hline NKp30 & - & $0.3677(p=0.1010)$ & $0.2671(p=0.2417)$ & $0.3910(p=0.0795)$ \\
\hline \multicolumn{5}{|c|}{$\mathrm{CD}^{2} 6^{\mathrm{dim}} \mathrm{NK}$ subset } \\
\hline \multicolumn{5}{|c|}{ Healthy donors } \\
\hline NKp46 & $0.7838(\mathrm{p}<0.0001)$ & $0.2220(p=0.2861)$ & $-0.1461(p=0.4859)$ & NA \\
\hline NKp30 & - & $0.2208(p=0.2889)$ & $0.0192(p=0.9273)$ & NA \\
\hline \multicolumn{5}{|c|}{ HIV/AIDS group } \\
\hline NKp46 & $0.9297(\mathrm{p}<0.0001)$ & $0.2213(p=0.2877)$ & $0.1986(p=0.3412)$ & $0.0962(p=0.6473)$ \\
\hline NKp30 & - & $0.3037(p=0.1399)$ & $0.3446(p=0.0916)$ & $0.1946(p=0.3512)$ \\
\hline \multicolumn{5}{|c|}{ HIV/AIDSWC group } \\
\hline NKp46 & $0.7156(p=0.0003)$ & $0.3558(p=0.1133)$ & $0.0864(p=0.7095)$ & $0.1039(p=0.6540)$ \\
\hline NKp30 & - & $0.3571(p=0.1119)$ & $0.3112(p=0.1696)$ & $0.4727(p=0.0504)$ \\
\hline \multicolumn{5}{|c|}{ CD56 ${ }^{\text {bright }} \mathrm{NK}$ subset } \\
\hline \multicolumn{5}{|c|}{ Healthy donors } \\
\hline NKp46 & $0.7121(\mathrm{p}<0.0001)$ & $0.6241(p=0.0008)$ & $0.0698(p=0.7402)$ & NA \\
\hline NKp30 & - & $0.6232(p=0.0009)$ & $0.2029(p=0.3307)$ & NA \\
\hline \multicolumn{5}{|c|}{ HIV/AIDS group } \\
\hline NKp46 & $0.3303(p=0.1068)$ & $0.3947(p=0.0508)$ & $0.0571(p=0.7863)$ & $0.2101(p=0.3135)$ \\
\hline NKp30 & - & $0.0987(p=0.6386)$ & $0.1911(p=0.3600)$ & $0.3172(p=0.1222)$ \\
\hline \multicolumn{5}{|c|}{ HIV/AIDSWC group } \\
\hline NKp46 & $0.8096(\mathrm{p}<0.0001)$ & $0.3094(p=0.1722)$ & $-0.0091(p=0.9687)$ & $-0.1055(p=0.6489)$ \\
\hline NKp30 & - & $0.2354(p=0.3043)$ & $0.0524(p=0.8215)$ & $0.0975(p=0.6743)$ \\
\hline
\end{tabular}

The numbers are shown as "rs $(p)$ ". $p<0.05$. Significant $p$ values are highlighted in bold. The correlation coefficient rs $>0$ shows positive correlation; rs $<0$ stands for negative correlation. $p<0.05$ and rs $>0.4$ indicates the significant correlation between the two indexes. NA: not applicable.

Since the advent of HAART, researchers have shown different degrees of recovery distribution in lymphocyte subpopulations, which may explain the lack of significant differences in the distribution of NK cells (and their subtypes) $[23,24]$ as well as lymphocyte $\mathrm{T}$ cells [19]. In contrast, Tarazona et al. [25] found a selective reduction of the subtype CD56 ${ }^{\mathrm{dim}}$ and preservation of the subtype CD56 ${ }^{\text {bright }}$. Other authors also observed reduction in the distribution of NK cells [26-28]. This reduction appears to be partially attributable to the emergence of a novel subset of $\mathrm{NK}$ cells that is rare in healthy individuals, $\mathrm{CD}^{-} \mathrm{CD} 56^{-} \mathrm{CD} 16^{+}$ NK cells that were described during chronic infections by HIV/AIDS [29]. These cells express a similar receptor profile for CD56 ${ }^{\mathrm{dim}} \mathrm{NK}$ cells but are relatively cytotoxic and do not secrete cytokines. Due to the lack of appropriate markers, this subpopulation cannot be tested in our study.

4.2. Expression of CD336 (NKp44). The NKp44 expression is only induced in activated NK cells and has been shown to be overexpressed in HIV+ patients with low levels of $\mathrm{CD}^{+}$
$\mathrm{T}$ cells [13]. In our study, the expression of NKp44 in the studied cells does not show considerable levels (data not shown). More thorough ex vivo studies may assess if there are abnormalities in the expression of this receptor in these cells. However, Vieillard et al. [13] and Fausther-Bovendo et al. [30] observed an increase in NKp44 expression in HIV+ patients. In contrast, De Maria et al. [12] and Marras et al. [31] observed a decrease of the NKp44 functioning in HIV-1 infection and making the analysis divergent.

There is evidence that suggests that NK cells may be involved in the depletion of $\mathrm{CD}^{+} \mathrm{T}$ cells. It is known that, after infection by HIV-1, a significant fraction of $\mathrm{CD} 4^{+} \mathrm{T}$ cell subset expresses NKp44L, an activation ligand of the NKp44 receptor that is induced by a HIV gp41 peptide [13]. The NKp44L expression makes $\mathrm{CD} 4^{+} \mathrm{T}$ cells sensitive to lysis by NK cells process. This expression is strongly correlated with the decline in $\mathrm{CD} 4^{+}$cell count and increase of viral load [13]. The NKp44L function in the depletion of $\mathrm{CD} 4^{+} \mathrm{T}$ cells was confirmed in a study by Vieillard et al. [32]. Ward et al. [33] suggest that HIV-1 has acquired the ability to use NK cells 
to disarm the host immune system, triggering the selective killing of uninfected $\mathrm{CD} 4^{+} \mathrm{T}$ cells.

The activation of NKp44 can be induced by tumor cells [32]. Some studies showed that NKp44 and other NCRs usually have an important role in the lysis mediated by NK cells in various tumors, including carcinomas, melanomas, neuroblastomas, myeloid and lymphoblastic leukemia, multiple myeloma, and B cells transformed by the Epstein-Barr virus [34].

\subsection{Decreased Expression of CD335 (NKp46) and CD337} (NKp30). NKp46 is expressed by NK cells that are either activated or deactivated by sending activating intracellular signals by association with the $\mathrm{CD} 3 \zeta$ chain or the $\gamma$ chain FceRI receptor [35]. Thus, these receptors, in combination with the NKG2D, are seen as being responsible for the spontaneous cytotoxic activity of NK cells in humans against many diseases (e.g., melanomas, carcinomas, and B lymphocytes infected by the Epstein-Barr virus). In general, the level of NKp46 expression is directly correlated with the degree of cytotoxicity of NK cells [36]. The receptor NKp30 is selectively expressed on NK cells and is associated with the dendritic cells. Human dendritic cells express the ligand for NKp30, but this ligand is unknown until now [37]. This ligand also mediates the NK-DC interaction resulting in the activation of DC or their death limiting the supply of dendritic cells [37].

Our study found a decreased frequency of NKp46 ( $p=$ $0.0012)$ and NKp30 $(p=0.0144)$ in NK cells in the HIV/AIDS group. Previous studies have also sought to assess the overall expression of NCR receptors in $\mathrm{HIV}+$, showing that HIV-1 leads to an overall decrease of NCRs [11-13]. According to De Maria et al. [12], there was a significant decrease in expression of NKp46 and NKp30 receptors on NK cells in HIV+ patients. The study of Frias et al. [11] also supports this analysis, when there was a lower expression of NKp46 and NKp30 receptors in NK cells of HIV+ patients.

HIV-1 also induces functional changes in the activation of NK cells $[12,14]$. For example, the activation with the K562 cell line was shown to reduce expression of CD16 and suppress the ability of $\mathrm{NK}$ cells to respond to additional stimulation [38]. These data suggest that NK cells in HIV1 patients, in vitro, have a considerable decrease in NCR activation, which is consistent with a decrease in expression of NKp46 and NKp30 molecules observed in NK cells in peripheral blood. The reduced expression of NCR in NK cells found in our study could be responsible, at least partially, for decreased lytic activity against the virus or tumor cells. These results suggest that modulation of receptor expression on NK cells may play a role in the pathogenesis of HIV-1 and provide new insights into immunologic alterations in advanced stages of the disease [35].

Our study found a partial recovery in the expression of NKp46 and NKp30 receptor in NK cells in the HIV/AIDSWC group, which, despite being lower than in the group of healthy donors, was not statistically significant. It is known that the release of cytokines in the tumor microenvironment can induce the expression of these receptors. Different cells can participate in this modulation, such as Th17. Studies show that these cells can directly mediate the antitumor response through the effector cell recruitment to the tumor microenvironment $[15,16]$. One way is through IL-17 produced by these cells which acts synergistically with the IFN inducing the production of chemokines CXCL10 and CXCL9 by malignant cells and macrophages, which induces the cell traffic that conducts antitumor functions [39]. Moreover, the ability of NK cells is increased in the presence of IL-17, since this increases cytokine expression of cytotoxic molecules such as TNF, IFN- $\gamma$, perforins, and granzymes B and NK cell activation receptors (NKp46, NKp44, NTB-A, and NKG2D) [40].

Another possibility for our results is the fact that the most common malignancies in the HIV/AIDSWC group induce the production of IL-12. Previous studies developed in cell culture have demonstrated that IL-12 has induced the expression of these receptors [41, 42]. It is known that the production of cytokines such as IL-15 and IL18 have similar effects and may also act in the activation and subsequent expression of NKp46 [43, 44]. The various cancers and oncoviruses associated with HIV-1 (which is a majority of the tumor manifestations found in our group with HIV/AIDSWC) are capable of overactivating such inflammatory responses by the secretion of these proinflammatory cytokines and chemotaxis and extravasation of lymphocytes by the site of infection $[45,46]$.

Our data suggest that although the cancer and its associated inflammatory processes stimulate the expression of NKp30 and NKp46 in NK cells in chronic conditions of HIV/AIDS, this expression leads to a less severe manner, keeping these receptors expressed at a subnormal level but higher than the HIV/AIDS patients without cancer. These preliminary findings increase the interest in the role of $\mathrm{NK}$ cells and its receptors in conducting a cancer process and the history of infection, considering that the expressions of NCRs decrease along the progression of the disease [12]. It is possible that during this HIV/AIDS progression the increase in these NCRs represents an immunological indicative of cancer and other systemic inflammatory conditions.

In addition, the NCR expression in cancer patients at normal or subnormal levels can be crucial to the survival rates of the patient, because it is known that the expression of these receptors is also associated with a good prognosis [47]. Our study design did not allow us to analyze the prognosis of these patients. In this respect, we suggest other longitudinal studies to better understand the differences in the distribution of these receptors and allow monitoring of these changes over a longer period in order to relate changes in NCRs with the incidence of cancers or prognosis of cancer group to relate it to the expressions of NCRs. Many aspects need to be clarified in future studies. For example, measurements of inflammatory markers and immune activation of NK cells need to be made to actually establish a factual influence of the tumor microenvironment and to determine the implications of such systemic exposure in NK cells with the significant increase of the NCRs in the HIV/AIDSWC group when compared to the HIV/AIDS group.

Regarding the influence of HAART use in the expression of receptors, Michaëlsson et al. [47] analyzed the frequency 
of NKp30+ and NKp46+ cells in patients with and without treatment. Although the monitoring was only one year, they found no clear differences between the patients who had been treated and those who had not. Frias et al. [11] also did not obtain a direct relationship between the use of HAART and the recovery of these receptors. However, the same study noted that the period with an undetectable viral load was related to increased recovery of NKp30 and NKp46. This finding suggests that although long-term use of HAART does not induce a direct recovery of NCRs, more prolonged use may lead to the restoration of the innate immunity and consequently viral suppression, and in the long-term in patients older than 85 months at load, an "undetectable" could result in improved expression of NCRs, even at levels below that of healthy people. However, none of the patients in our study had an extended period of viral suppression in order to provide such recovery.

Through our correlation analysis, it was possible to observe an association between NKp46 and NKp30 receptors in all groups. These results were expected from previous studies including De Maria et al. [12], Wong et al. [35], and Lu et al. [40], since both receptors are constitutive NK cells, and expression levels of these receptors are subject to the similar variables and condition esplanades in our study. The only exception was in CD56 $6^{\text {bright }}$ cells in HIV/AIDS patients without cancer that were not correlated ( $r s=0.3303$, $p=0.10680)$. It is possible that there are repercussions of HIV/AIDS in CD56 $6^{\text {bright }}$, and these are poorly known.

Regarding the influence of other parameters in the expression of these receptors, our analysis allowed us to establish any correlation between these and the CD4 T cell numbers, CD4/CD8 ratio, and days of infection. These data are consistent with the findings of Frias et al. [11], which did not observe influence of these variables in the expression of NCRs.

Regarding the relationship observed between NKp46 (rs $=0.6241, p=0.0008)$ and NKp30 ( $\mathrm{rs}=0.6232, p=0.0009)$ receptors and $\mathrm{CD}^{+}{ }^{+} \mathrm{T}$ cells in CD56 $6^{\text {bright }}$ cells in healthy donors, it is possible that there are mechanisms of interaction between $\mathrm{NK}^{\text {bright }}$ cells and $\mathrm{CD} 4^{+} \mathrm{T}$ cells that may be related to expression of NCRs [48]. However, the forms of interaction between these cells are still poorly known, particularly the repercussions of these interactions in HIV/AIDS.

Finally, we hope that this study may contribute to understanding natural cytotoxicity receptors in patients with HIV/AIDS and cancer. It is crucial to consider that changes in NCRs may result in the history of the diseases as well as loss of efficiency in the monitoring of cancer cells by NK cells that together with the immunosuppression context of HIV/AIDS are critical in the beginning and throughout the evolution of these neoplastic diseases. We emphasize the need to study other types of receptors on NK cells such as lectin and KIR in patients with cancer and chronic HIV/AIDS to bring more depth to the subject.

4.4. Study Limitations. The technical limitations of this study include a lack of auxiliary markers to observe the
$\mathrm{CD}^{-} 6^{-} \mathrm{CD} 16^{+}$population (NK CD56 ${ }^{\text {neg }}$ ) and the impossibility of activation of NK cells ex vivo (NKp44+) to assess if there are abnormalities in the expression of this receptor in these cells.

We cannot correlate the decreased expression of the NCRs with the function of the NK cell. A FACS-based cytotoxicity assay or cytokine production assessment would be extremely helpful to establish the functional consequences of NCR downmodulation.

The limitations of this study include a small sample size, a single-centered hospital-based study, and the impossibility of stratification to sex, age, cancer type, and treatment (HIV/AIDS as well as cancer).

\section{Conclusion}

There were no changes in the distribution of NK cells and their subtypes in either of the groups. Decreased expression of receptors NKp46 and NKp30 was observed in the HIV/AIDS group. The expression of NCR in NK cells in patients with HIV/AIDS and cancer was shown to be higher in HIV/AIDS patients without cancer.

More studies are needed that consider larger study groups and include the possibility of stratifying results to see if these findings are persistent in groups of different genders and treatments and, in the case of cancer patients, their cancers. It is necessary to determine if the changing balance of NK receptor expression may influence susceptibility to various diseases such as infections and cancer.

\section{Competing Interests}

The authors have no conflict of interests that are directly relevant to the content of this paper.

\section{Authors' Contributions}

Orlando Nascimento Terra Junior, Hilda Rachel Diamond, and Maria Helena Faria Ornellas de Souza designed the experiments. Gabriel de Carvalho Maldonado and Dirce Bonfim de Lima recruited the patients for the study. Orlando Nascimento Terra Junior and Vinicius da Cunha Lisboa performed the experiments. Orlando Nascimento Terra Junior and Adriano Arnóbio analyzed the data and the statistical analysis. Guilherme Rohem Alfradiq edited the image and the tables. Orlando Nascimento Terra Junior, Gabriel de Carvalho Maldonado, Guilherme Rohem Alfradiq, Vinicius da Cunha Lisboa, Adriano Arnóbio, Dirce Bonfim de Lima, Hilda Rachel Diamond, and Maria Helena Faria Ornellas de Souza edited and revised the paper. All authors read and approved the final paper.

\section{Acknowledgments}

This work was supported by the World Bank, United Nations Office on Drugs and Crime (UNODC) and Ministério da Saúde (Brazil), Departamento de DST, Aids e Hepatites Virais (Brazil), CAPES, and FAPERJ. 


\section{References}

[1] S. F. Plaeger, B. S. Collins, R. Musib, S. G. Deeks, S. Read, and A. Embry, "Immune activation in the pathogenesis of treated chronic HIV disease: a workshop summary," AIDS Research and Human Retroviruses, vol. 28, no. 5, pp. 469-477, 2012.

[2] E. A. Engels, R. J. Biggar, H. I. Hall et al., "Cancer risk in people infected with human immunodeficiency virus in the United States," International Journal of Cancer, vol. 123, no. 1, pp. 187194, 2008.

[3] M. S. Shiels, R. M. Pfeiffer, M. H. Gail et al., "Cancer burden in the HIV-infected population in the United States," Journal of the National Cancer Institute, vol. 103, no. 9, pp. 753-762, 2011.

[4] P. G. Rubinstein, D. M. Aboulafia, and A. Zloza, "Malignancies in HIV/AIDS: from epidemiology to therapeutic challenges," AIDS, vol. 28, no. 4, pp. 453-465, 2014.

[5] G. M. Clifford, J. Polesel, M. Rickenbach et al., "Cancer risk in the Swiss HIV Cohort Study: associations with immunodeficiency, smoking, and highly active antiretroviral therapy," Journal of the National Cancer Institute, vol. 97, no. 6, pp. 425432, 2005.

[6] M. J. Silverberg, C. Chao, W. A. Leyden et al., "HIV infection and the risk of cancers with and without a known infectious cause," AIDS, vol. 23, no. 17, pp. 2337-2345, 2009.

[7] A. Almeida-Oliveira, M. Smith-Carvalho, L. C. Porto et al., "Age-related changes in natural killer cell receptors from childhood through old age," Human Immunology, vol. 72, no. 4, pp. 319-329, 2011.

[8] S. Jost and M. Altfeld, "Evasion from NK cell-mediated immune responses by HIV-1," Microbes and Infection, vol. 14, no. 11, pp. 904-915, 2012.

[9] G. G. Halfteck, M. Elboim, C. Gur, H. Achdout, H. Ghadially, and O. Mandelboim, "Enhanced in vivo growth of lymphoma tumors in the absence of the NK-activating receptor NKp46/NCR1," The Journal of Immunology, vol. 182, no. 4, pp. 2221-2230, 2009.

[10] M. Elboim, R. Gazit, C. Gur, H. Ghadially, G. Betser-Cohen, and O. Mandelboim, "Tumor immunoediting by NKp46," The Journal of Immunology, vol. 184, no. 10, pp. 5637-5644, 2010.

[11] M. Frias, A. Rivero-Juarez, A. Gordon et al., "Persistence of pathological distribution of NK cells in HIV-infected patients with prolonged use of HAART and a sustained immune response," PLoS ONE, vol. 10, no. 3, Article ID e0121019, 2015.

[12] A. De Maria, M. Fogli, P. Costa et al., "The impaired NK cell cytolytic function in viremic HIV-1 infection is associated with a reduced surface expression of natural cytotoxicity receptors (NKp46, NKp30 and NKp44)," European Journal of Immunology, vol. 33, no. 9, pp. 2410-2418, 2003.

[13] V. Vieillard, J. L. Strominger, and P. Debre, "NK cytotoxicity against $\mathrm{CD}^{+} \mathrm{T}$ cells during HIV-1 infection: a gp41 peptide induces the expression of an NKp44 ligand," Proceedings of the National Academy of Sciences of the United States of America, vol. 102, no. 31, pp. 10981-10986, 2005.

[14] M. Fogli, P. Costa, G. Murdaca et al., "Significant NK cell activation associated with decreased cytolytic function in peripheral blood of HIV-1-infected patients," European Journal of Immunology, vol. 34, no. 8, pp. 2313-2321, 2004.

[15] P. Gaur, G. A. Qadir, S. Upadhyay et al., "Skewed immunological balance between Th17 $\left(\mathrm{CD}^{+} \mathrm{IL}_{17 \mathrm{~A}^{+}}\right)$and Treg $\left(\mathrm{CD}^{+} \mathrm{CD}^{2} 5^{+} \mathrm{FOXP}^{+}\right)$cells in human oral squamous cell carcinoma," Cellular Oncology, vol. 35, no. 5, pp. 335-343, 2012.
[16] S. R. Bailey, M. H. Nelson, R. A. Himes, Z. Li, S. Mehrotra, and C. M. Paulos, "Th17 cells in cancer: the ultimate identity crisis," Frontiers in Immunology, vol. 5, article 276, 2014.

[17] S. G. Deeks, R. Tracy, and D. C. Douek, "Systemic effects of inflammation on health during chronic HIV infection," Immunity, vol. 39, no. 4, pp. 633-645, 2013.

[18] P. Borrow and N. Bhardwaj, "Innate immune responses in primary HIV-1 infection," Current Opinion in HIV and AIDS, vol. 3, no. 1, pp. 36-44, 2008.

[19] M. Horberg, M. Silverberg, L. Hurley, G. Delorenze, and C. Quesenberry, "Influence of prior antiretroviral experience on adherence and responses to new highly active antiretroviral therapy regimens," AIDS Patient Care and STDs, vol. 22, no. 4, pp. 301-312, 2008.

[20] V. Naranbhai, M. Altfeld, S. S. A. Karim, T. Ndung'u, Q. Abdool Karim, and W. H. Carr, "Changes in Natural Killer cell activation and function during primary HIV-1 infection," PLoS ONE, vol. 8, no. 1, Article ID e53251, 2013.

[21] P. W. Hunt, N. S. Shulman, T. L. Hayes et al., “The immunologic effects of maraviroc intensification in treated HIV-infected individuals with incomplete CD4+ T-cell recovery: a randomized trial," Blood, vol. 121, no. 23, pp. 4635-4646, 2013.

[22] G. Alter, N. Teigen, B. T. Davis et al., "Sequential deregulation of NK cell subset distribution and function starting in acute HIV-1 infection," Blood, vol. 106, no. 10, pp. 3366-3369, 2005.

[23] D. Mavilio, J. Benjamin, M. Daucher et al., "Natural killer cells in HIV-1 infection: dichotomous effects of viremia on inhibitory and activating receptors and their functional correlates," Proceedings of the National Academy of Sciences of the United States of America, vol. 100, no. 25, pp. 15011-15016, 2003.

[24] Y. Jiang, L. He, H. Chen et al., "Alteration of inhibitory and activating NK cell receptor expression on NK cells in HIVinfected Chinese," Cellular Immunology, vol. 271, no. 2, pp. 219226, 2011.

[25] R. Tarazona, J. G. Casado, O. Delarosa et al., "Selective depletion of CD56 ${ }^{\mathrm{dim}}$ NK cell subsets and maintenance of CD56 $6^{\text {bright }}$ NK cells in treatment-naive HIV-1-seropositive individuals," Journal of Clinical Immunology, vol. 22, no. 3, pp. 176-183, 2002.

[26] L. Azzoni, E. Papasavvas, J. Chehimi et al., "Sustained impairment of IFN- $\gamma$ secretion in suppressed HIV-infected patients despite mature NK cell recovery: evidence for a defective reconstitution of innate immunity," The Journal of Immunology, vol. 168, no. 11, pp. 5764-5770, 2002.

[27] G. Alter, J. M. Malenfant, R. M. Delabre et al., "Increased natural killer cell activity in viremic HIV-1 infection," The Journal of Immunology, vol. 173, no. 8, pp. 5305-5311, 2004.

[28] P. Mantegani, G. Tambussi, L. Galli et al., "Perturbation of the natural killer cell compartment during primary human immunodeficiency virus 1 infection primarily involving the CD56 bright subset," Immunology, vol. 129, no. 2, pp. 220-233, 2010.

[29] D. Mavilio, G. Lombardo, J. Benjamin et al., "Characterization of $\mathrm{CD}^{-} 6^{-} / \mathrm{CD} 16^{+}$natural killer (NK) cells: a highly dysfunctional NK subset expanded in HIV-infected viremic individuals," Proceedings of the National Academy of Sciences of the United States of America, vol. 102, no. 8, pp. 2886-2891, 2005.

[30] P. H. Fausther-Bovendo, V. Vieillard, S. Sagan, G. Bismuth, and P. Debré, "HIV gp41 engages gClqR on CD4+ T cells to induce the expression of an NK ligand through the PIP3/ $\mathrm{H}_{2} \mathrm{O}_{2}$ pathway," PLoS Pathogens, vol. 6, no. 7, Article ID e1000975, 2010. 
[31] F. Marras, E. Nicco, F. Bozzano et al., "Natural killer cells in HIV controller patients express an activated effector phenotype and do not up-regulate NKp44 on IL-2 stimulation," Proceedings of the National Academy of Sciences of the United States of America, vol. 110, no. 29, pp. 11970-11975, 2013.

[32] V. Vieillard, R. E. Habib, P. Brochard et al., "CCR5 or CXCR4 use influences the relationship between CD4 cell depletion, NKp44L expression and NK cytotoxicity in SHIV-infected macaques," AIDS, vol. 22, no. 2, pp. 185-192, 2008.

[33] J. Ward, M. Bonaparte, J. Sacks et al., "HIV modulates the expression of ligands important in triggering natural killer cell cytotoxic responses on infected primary T-cell blasts," Blood, vol. 110, no. 4, pp. 1207-1214, 2007.

[34] B. Rosental, M. Brusilovsky, U. Hadad et al., "Proliferating cell nuclear antigen is a novel inhibitory ligand for the natural cytotoxicity receptor NKp44," The Journal of Immunology, vol. 187, no. 11, pp. 5693-5702, 2011.

[35] A. H. W. Wong, K. Williams, S. Reddy et al., "Alterations in natural killer cell receptor profiles during HIV type 1 disease progression among chronically infected South African adults," AIDS Research and Human Retroviruses, vol. 26, no. 4, pp. 459469, 2010 .

[36] F. Bisio, F. Bozzano, F. Marras, A. Di Biagio, L. Moretta, and A. De Maria, "Successfully treated HIV-infected patients have differential expression of NK cell receptors (NKp46 and NKp30) according to AIDS status at presentation," Immunology Letters, vol. 152, no. 1, pp. 16-24, 2013.

[37] M. Vitale, M. Della Chiesa, S. Carlomagno et al., "NKdependent DC maturation is mediated by TNF $\alpha$ and IFN $\gamma$ released upon engagement of the NKp30 triggering receptor," Blood, vol. 106, no. 2, pp. 566-571, 2005.

[38] B. Grzywacz, N. Kataria, and M. R. Verneris, "CD56 ${ }^{\operatorname{dim}} \mathrm{CD} 16^{+}$ NK cells downregulate CD16 following target cell induced activation of matrix metalloproteinases," Leukemia, vol. 21, no. 2, pp. 356-359, 2007.

[39] W. Zou and N. P. Restifo, " $\mathrm{T}_{H} 17$ cells in tumour immunity and immunotherapy," Nature Reviews Immunology, vol. 10, no. 4, pp. 248-256, 2010.

[40] L. Lu, K. Pan, H.-X. Zheng et al., "IL-17A promotes immune cell recruitment in human esophageal cancers and the infiltrating dendritic cells represent a positive prognostic marker for patient survival," Journal of Immunotherapy, vol. 36, no. 8, pp. 451-458, 2013.

[41] S. S. Li, S. K. Kyei, M. Timm-Mccann et al., "The NK receptor NKp30 mediates direct fungal recognition and killing and is diminished in NK cells from HIV-infected patients," Cell Host \& Microbe, vol. 14, no. 4, pp. 387-397, 2013.

[42] I. Hromadnikova, P. Pirkova, and L. Sedlackova, "Influence of in vitro IL-2 or IL-15 alone or in combination with Hsp-70-derived 14-mer peptide (TKD) on the expression of NK cell activatory and inhibitory receptors," Mediators of inflammation, vol. 2013, Article ID 405295, 12 pages, 2013.

[43] A. Ziblat, C. I. Domaica, R. G. Spallanzani et al., "IL-27 stimulates human NK-cell effector functions and primes NK cells for IL-18 responsiveness," European Journal of Immunology, vol. 45, no. 1, pp. 192-202, 2015.

[44] V. R. Parasa, A. Selvaraj, R. Sikhamani, and A. Raja, "Interleukins 15 and 12 in combination expand the selective loss of natural killer T cells in HIV infection in vitro," Clinical and Experimental Medicine, vol. 15, no. 2, pp. 205-213, 2015.

[45] E. Vendrame, S. K. Hussain, E. C. Breen et al., "Serum levels of cytokines, and biomarkers for inflammation and immune activation, and HIV-associated non-hodgkin B cell lymphoma risk," Cancer Epidemiology, Biomarkers \& Prevention, vol. 23, pp. 343-349, 2014.

[46] L. Giffin and B. Damania, "KSHV: pathways to tumorigenesis and persistent infection," Advances in Virus Research, vol. 88, pp. 111-159, 2014.

[47] J. Michaëlsson, B. R. Long, C. P. Loo et al., "Immune reconstitution of CD56 ${ }^{\mathrm{dim}}$ NK cells in individuals with primary HIV-1 infection treated with interleukin-2," The Journal of Infectious Diseases, vol. 197, no. 1, pp. 117-125, 2008.

[48] A. Poli, T. Michel, M. Thérésine, E. Andrès, F. Hentges, and J. Zimmer, "CD56bright natural killer (NK) cells: an important NK cell subset," Immunology, vol. 126, no. 4, pp. 458-465, 2009. 


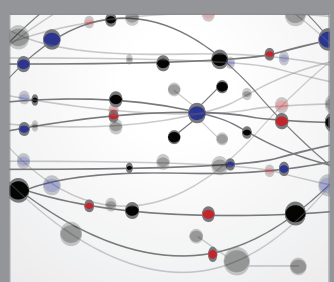

The Scientific World Journal
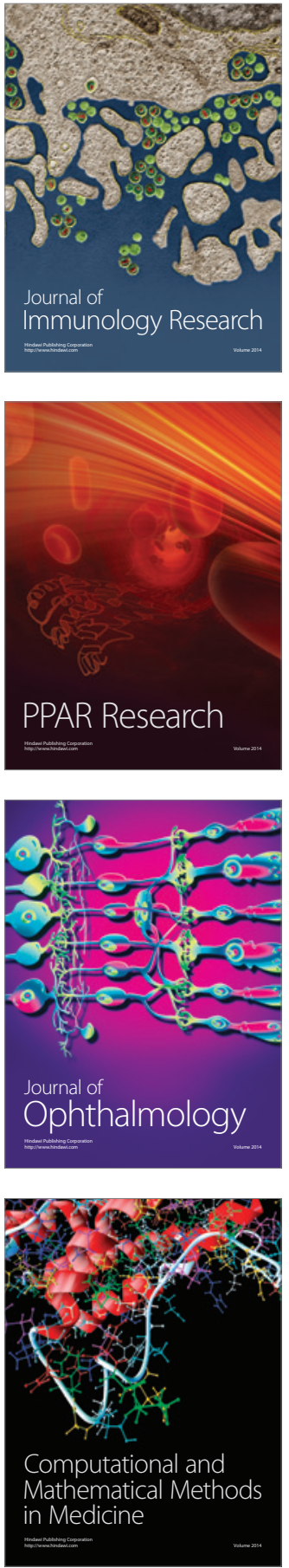

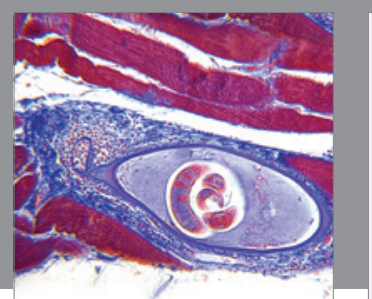

Gastroenterology Research and Practice

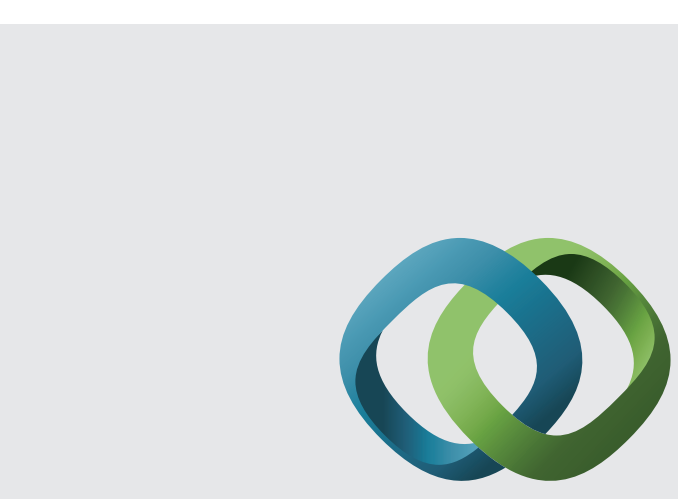

\section{Hindawi}

Submit your manuscripts at

http://www.hindawi.com
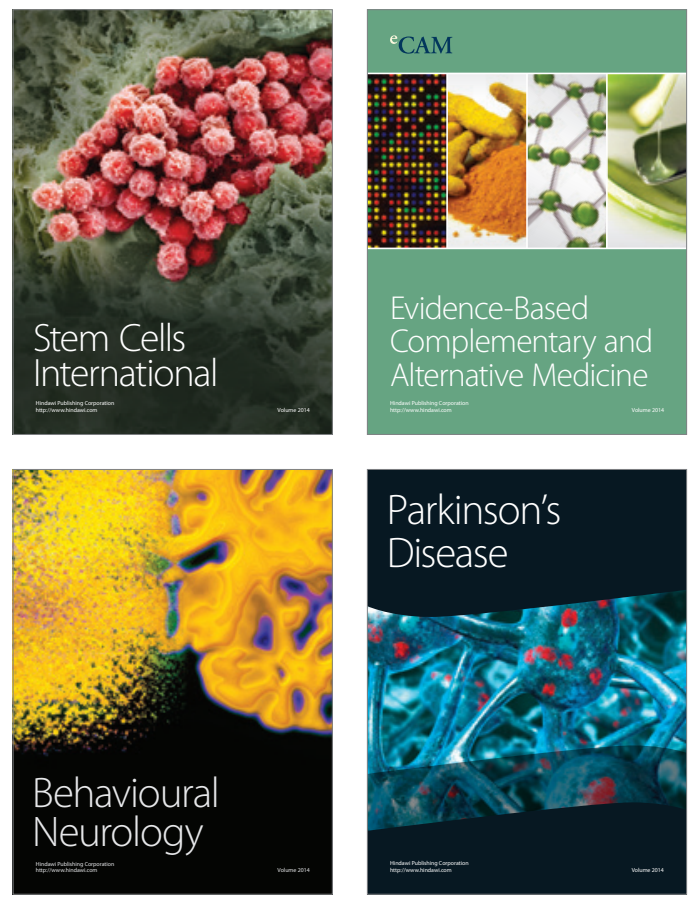
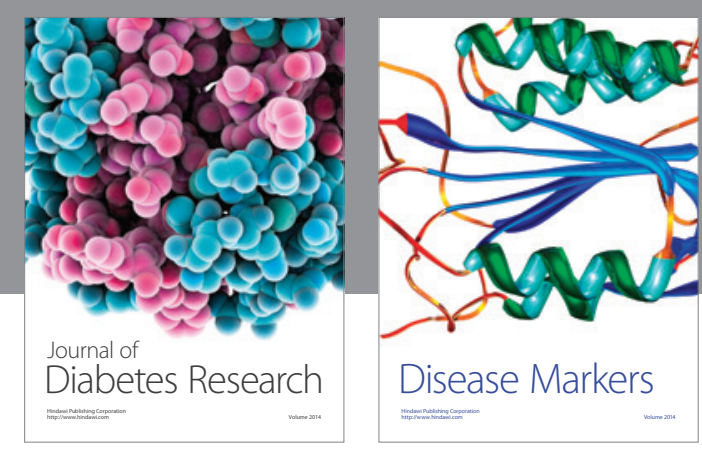

Disease Markers
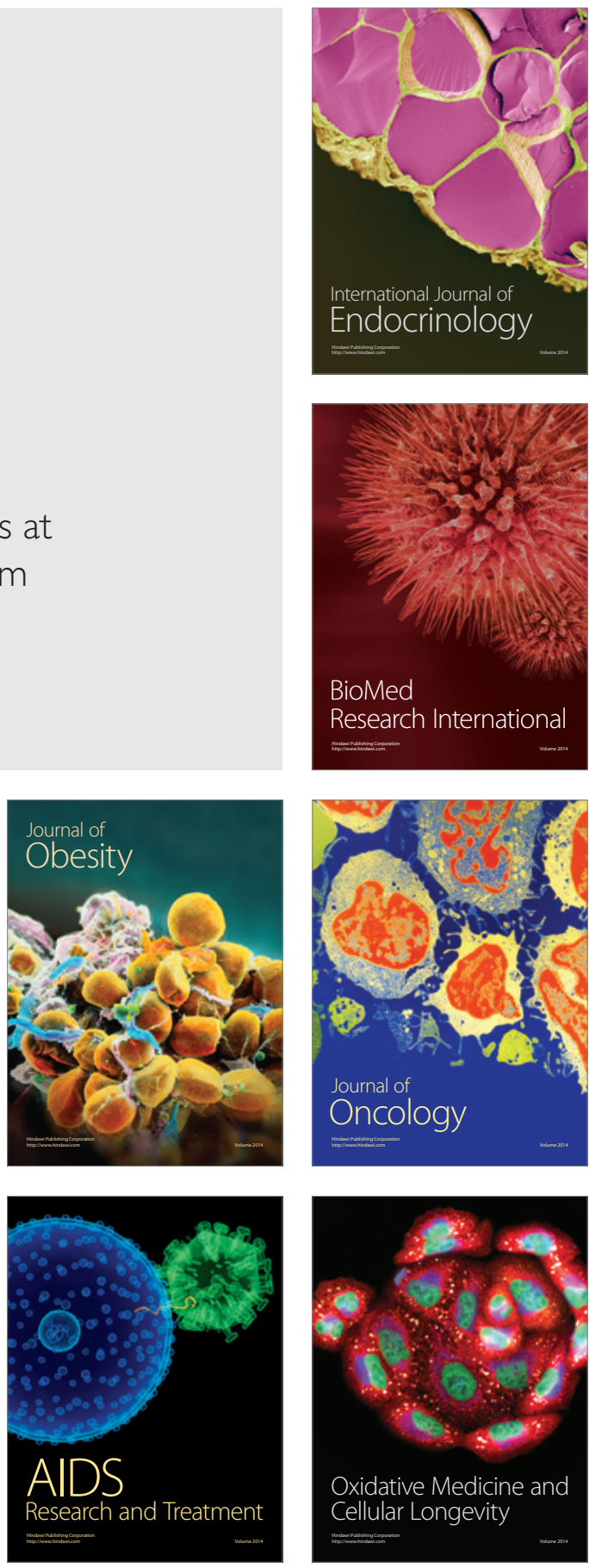